\title{
Evaluasi model Kirkpatrick terhadap kegiatan Design Camp \#1: bamboo for creative millennials
}

\author{
Kristian Oentoro*
}

Program Studi Desain Produk, Universitas Kristen Duta Wacana, Yogyakarta, Indonesia

\begin{abstract}
Design Camp \#1 is the national workshop for product design students which involve 28 stu participants from 14 public/private colleges in Indonesia. The theme of Bamboo for Creative Millennials was raised to encouraged the participants to work together with bamboo craftsmen at Sendari Bamboo Crafts Center, Sleman, D.I. Yogyakarta. As the first program carried out, Design Camp \# 1 requires evaluative research so that the process of implementing the next activity can continue to be developed. The Kirkpatrick model is applied to find out four levels of evaluation, including reactions, learning, behavior, and results. The research method used is quantitative descriptive, while the data collection uses interview techniques and online surveys. The results of the reaction evaluation showed that 52.5\% of participants were very satisfied with aspects of the implementation (design materials, craft mentors, organizers, and support of each college). Learning evaluation shows that participants can learn bamboo processing skills (75\%) and knowledge of bamboo design (67.8\%). Participants also showed good collaboration in the work process, even in the evaluation of behavior $38 \%$ of aspects of success were determined by a group of friends. Design Camp \# 1 activity produced 10 prototypes and $67.8 \%$ of participants were interested in developing their design ideas. The evaluation results also showed that $60.7 \%$ of participants strongly agreed that this activity could support a career as a product designer.
\end{abstract}

Key words: design, evaluation, Kirkpatrick, bamboo

\begin{abstract}
Abstrak
Design Camp \#1 merupakan kegiatan pelatihan bagi mahasiswa desain produk tingkat nasional yang melibatkan 28 mahasiswa dari 14 institusi pendidikan (PTS/PTN) di Indonesia. Tema Bamboo for Creative Millennials yang diangkat mendorong para peserta untuk berkarya bersama perajin bambu di Sentra Kerajinan Bambu Sendari, Sleman, D.I.Yogyakarta. Sebagai kegiatan yang pertama kali dilaksanakan, Design Camp \#1 membutuhkan penelitian evaluatif agar proses pelaksanaan kegiatan berikutnya dapat terus dikembangkan. Model Kirkpatrick diterapkan untuk mengetahui empat tingkatan evaluasi, antara lain reaksi, pembelajaran, perilaku, dan hasil. Metode penelitian yang digunakan adalah deskriptif kuantitatif, sedangkan pengumpulan datanya menggunakan teknik wawancara dan survei daring. Hasil evaluasi reaksi menunjukkan bahwa 52,5\% peserta merasa sangat puas terhadap aspek-aspek pelaksanaan (materi desain, mentor perajin, penyelenggara, dan dukungan masing-masing kampus). Evaluasi pembelajaran menunjukkan bahwa peserta dapat belajar keterampilan olah bambu (75\%) dan pengetahuan tentang desain bambu (67,8\%). Peserta juga menunjukkan kolaborasi yang baik dalam proses berkarya, bahkan dalam evaluasi perilaku 38\% aspek keberhasilan ditentukan oleh teman sekelompok. Kegiatan Design Camp \#1 menghasilkan 10 purwarupa dan sebanyak 67,8\% peserta tertarik untuk mengembangkan ide desainnya. Hasil evaluasi juga menunjukkan bahwa 60,7\% peserta sangat setuju bahwa kegiatan ini dapat mendukung karir sebagai desainer produk.
\end{abstract}

Kata kunci: serveware, kayu, gerabah, finishing, penyajian makanan

\section{Pendahuluan}

Masa depan bidang desain produk di Indonesia sangat dipengaruhi oleh arah institusi pendidikan desain produk yang ditempuh oleh para mahasiswa saat ini. Perkembangan profesi desainer produk di Indonesia juga semakin membutuhkan pemikiran yang kreatif dan kritis dalam pemecahan masalah desain. Oleh karena itu, upaya peningkatan kualitas pendidikan serta kapasitas mahasiswa desain produk

\footnotetext{
* Corresponding author Tel : +62-819-0420-4080; e-mail: kristian@staff.ukdw.ac.id
} 
di Indonesia menjadi kunci dalam memenangkan persaingan global dalam industri kreatif. Rowe \& Sandra (2011) berpendapat bahwa pendidikan desain di abad 21 saat ini belum sepenuhnya mampu beradaptasi dengan peluang maupun tantangan yang dihadapi dalam dunia profesi. Seiring dengan perkembangan teknologi, mahasiswa desain produk juga akan menghadapi masalah yang semakin kompleks sehingga dituntut untuk bekerjasama satu dengan yang lain, bahkan mampu berpikir secara multidisiplin dalam proses kreatif (Komnenić, dkk., 2015). Dengan demikian, maka kemampuan berkarya bagi desainer produk tidak hanya mengandalkan keterampilan berpikir (thinking) dan berkreasi (making), melainkan juga membutuhkan kemampuan untuk belajar (learning) dan berkolaborasi (collaborating).

Pembelajaran di bidang desain produk secara kolaboratif dewasa ini telah menjadi sebuah metode belajar yang efektif dalam membuka wawasan antar mahasiswa terhadap materi-materi baru. Metode pembelajaran secara kolaboratif inilah yang menjadi landasan pemikiran dalam menyelenggarakan kegiatan lintas program studi desain produk di tingkat nasional, yakni kegiatan Design Camp \#1 yang mengambil tema Bamboo for Creative Millennials pada tahun 2019. Selain mendorong pola belajar secara kolaboratif antar mahasiswa program studi desain produk, kegiatan ini juga memberikan kesempatan bagi mahasiswa untuk berkolaborasi dengan para perajin bambu sesuai dengan tema yang diangkat. Di sisi lain, kesempatan ini bagi pelaku usaha juga melatih kerjasama antara perajin bambu dengan mahasiswa selaku desainer produk di dalam lingkup Usaha Kecil Menengah (UKM). Meskipun desain produk bambu di Indonesia hingga saat ini berkembang cukup pesat, namun masih banyak pula pelaku usaha bambu yang kekurangan ide-ide desain bagi generasi milenial. Salah satunya adalah Sentra Kerajinan Bambu Sendari di Desa Tlogoadi, Kabupaten Sleman, D.I. Yogyakarta yang dipilih menjadi lokasi penyelenggaraan kegiatan Design Camp tahun 2019. Melalui skema kolaborasi antara akademisi dan pelaku industri, mahasiswa desain produk bersama para perajin bambu dapat berkarya dan mengembangkan desain produk bambu.

Pelaksanaan kegiatan Desain Camp \#1 tahun 2019 diorganisir oleh tim dari Program Studi Desain Produk, Universitas Kristen Duta Wacana yang merupakan salah satu anggota afiliasi Aliansi Desainer Produk Industri Indonesia (ADPII). Kegiatan ini juga diikuti oleh 28 mahasiswa Program Studi Desain Produk dari 14 Perguruan Tinggi Negeri
(PTN) maupun Perguruan Tinggi Swasta (PTS) di Indonesia. Masing-masing PTN/PTS diwakili oleh 2 orang mahasiswa sebagai peserta yang tinggal bersama di asrama selama 3 hari untuk mengikuti serangkaian kegiatan, seperti pengantar desain bambu, presentasi sketsa, materi pembekalan (coaching), pendampingan kelompok (mentoring), perwujudan purwarupa, hingga diakhiri dengan presentasi dan pameran karya untuk diberi penilaian. Menurut Westbomke, dkk (2011), kegiatan bersosialisasi dan berdiskusi di dalam keseharian para peserta justru memegang peran penting dari kegiatan Design Camp yang mampu memicu semangat dan kinerja bersama. Selain bermanfaat untuk menjalin keakraban, kegiatan yang mewajibkan peserta untuk tinggal bersama (саmp) juga menjadi pembelajaran untuk merefleksikan diri dalam komunitas sosial.

Pelaksanaan Desain Camp \#1 merupakan salah satu fenomena yang menarik sebagai kegiatan kemahasiswaan di tingkat nasional yang pertama kali diselenggarakan dalam lingkup anggota afiliasi ADPII. Keberagaman pengetahuan dan keterampilan mahasiswa yang berasal dari berbagai program studi desain produk di Indonesia juga perlu dikaji lebih dalam melalui proses evaluasi pelaksanaan kegiatan. Di samping itu, para mahasiswa sebagai peserta Design Camp \#1 juga berasal dari berbagai daerah di Indonesia yang memiliki perbedaan sudut pandang dalam berkarya dengan material bambu secara kolaboratif. Oleh karena itu, penelitian ini bertujuan untuk mengetahui aspek-aspek pelaksanaan kegiatan Design Camp \#1 secara menyeluruh yang meliputi aspek reaksi, pembelajaran, perilaku, dan hasil. Keempat aspek ini merupakan penjabaran dalam model evaluasi Kirkpatrick yang telah banyak digunakan dalam berbagai macam kegiatan pelatihan, akan tetapi belum banyak diterapkan dalam mengevaluasi kegiatan di bidang pendidikan desain produk. Dengan demikian, maka studi ini juga bermanfaat sebagai rujukan bagi penyelenggara kegiatan serupa dalam mengembangkan berbagai aspek dalam pelaksanaan kegiatan berikutnya. Sedangkan bagi kalangan akademisi dan pelaku industri bambu, hasil penelitian dapat memberikan gambaran tentang peran mahasiswa desain produk dalam mengembangkan desain kerajinan bambu secara kolaboratif yang dilakukan dalam waktu 3 hari. Durasi program yang relatif singkat dalam proses kreatif maupun proses perwujudan karya secara kolaboratif merupakan salah satu tantangan yang dihadapi mahasiswa, akan tetapi hal ini justru menjadi poin penting yang menjadi salah satu instrumen yang penting dalam penelitian ini. 


\section{Bahan dan Metode}

Penelitian evaluatif terhadap kegiatan Design Camp\#1 dilakukan dengan menggunakan model Kirkpatrick yang pada umumnya digunakan untuk mengulas kegiatan pembelajaran maupun pelatihan secara menyeluruh dengan kategorisasi tingkatan yang sederhana. Menurut Kirkpatrick \& Kirkpatrick (2016), evaluasi dalam setiap pelaksanaan kegiatan pembelajaran atau pelatihan bertujuan untuk meningkatkan kualitas, mengoptimalkan proses maupun hasil belajar, serta menunjukkan nilai-nilai pembelajaran. Evaluasi kegiatan Design Camp \#1 dikategorikan ke dalam 4 tingkatan, yakni reaksi (reaction), pembelajaran (learning), perilaku (behaviour), dan hasil (result). Keempat tingkatan tersebut dalam model evaluasi Kirkpatrick dipetakan sesuai dengan tujuan dan penekanan yang dimaksud. Gambar 1 memperlihatkan hirarki tingkatan model Kirkpatrick beserta alur penelitian.

Evaluasi model Kirkpatrick diawali dengan mengumpulkan reaksi (reaction) seluruh peserta terhadap penyelenggaraan kegiatan Design Camp \#1, terutama yang berkaitan dengan kepuasan, kesan, dan pandangan terkait dengan kegiatan ini. Menurut Badu (2012), kepuasan peserta dalam mengikuti kegiatan akan berpengaruh terhadap minat dan motivasi belajar. Peserta yang termotivasi akan lebih mudah dalam menerima proses pembelajaran dari berbagai sumber yang disediakan dalam oleh penyelenggara. Oleh karena itu, pembekalan kegiatan ini melibatkan 3 narasumber yang memberikan materi desain dan motivasi kepada para peserta sebelum proses berkarya dengan mitra UKM. Evaluasi pada tingkatan selanjutnya adalah evaluasi pembelajaran (learning) yang berkaitan dengan peningkatan pengetahuan dan keterampilan melalui kegiatan Design Camp \#1. Tahap awal evaluasi pembelajaran juga mencari tingkat kesesuaian peserta dengan tema yang diangkat dan tingkat kesesuaian kegiatan Design Camp \#1 dengan gambaran awal peserta. Sebagai pendukung muatan keterampilan berkarya, maka proses pembelajaran mahasiswa desain produk mendapat pendampingan dari perajin bambu dalam mewujudkan karya. Selanjutnya pada tahap ketiga adalah melakukan evaluasi perilaku peserta (behaviour) dalam mengikuti kegiatan Design Camp \#1. Evaluasi perilaku ini mengkaji kecenderungan peserta dalam mempertimbangkan aspek-aspek keberhasilan ketika bekerja dalam kelompok. Evaluasi hasil (result) merupakan tingkatan akhir yang membahas terkait pencapaian peserta dalam kegiatan Design Camp \#1, termasuk bagaimana peserta merespon kegiatan seperti ini di waktu yang akan datang.

Pembahasan dalam penelitian evaluasi model Kirkpatrick terhadap kegiatan Design Camp \#1 menerapkan metode deskriptif kuantitatif. Menurut Sugiyono (2012), penelitian deskriptif bertujuan untuk memberikan gambaran melalui analisis suatu data penelitian yang telah dikumpulkan sebelumnya. Selain melakukan wawancara mendalam kepada beberapa peserta Design Camp \#1, pengumpulan data penelitian juga didapat melalui kuesioner daring (online) yang menggunakan fitur pengisian data, yakni google form. Pengisian kuesioner paska pelatihan sebagai pendukung data evaluasi dilakukan dengan metode survei kepada 28 peserta Design Camp \#1. Syahrum \& Salim (2012) berpendapat bahwa tujuan dari penggunaan metode survei adalah untuk melakukan pengukuran respon hasil evaluasi

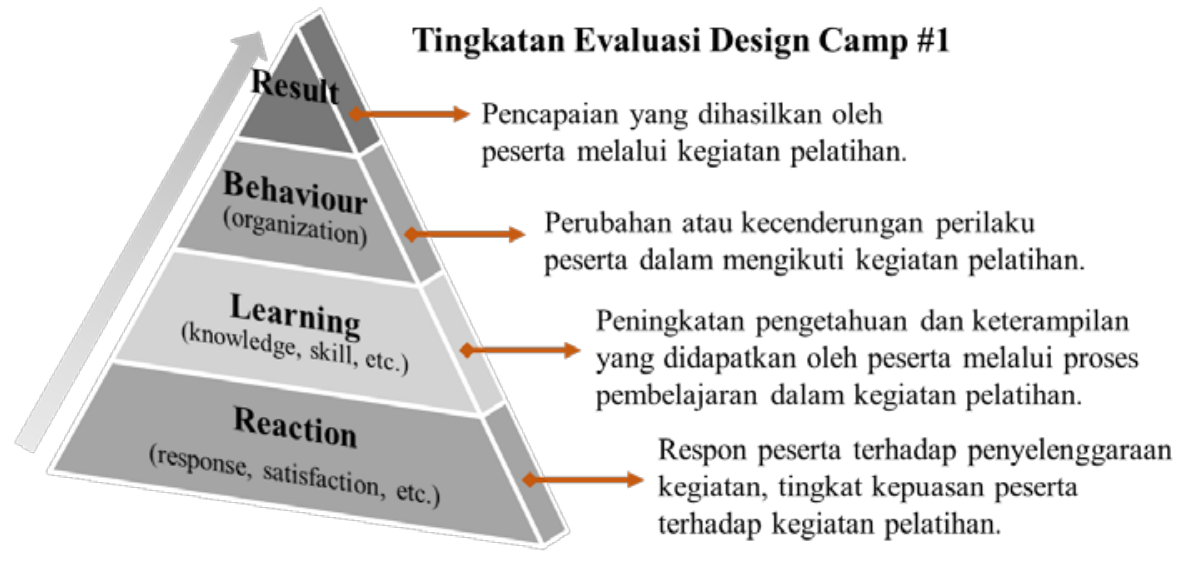

Gambar 1. Tingkatan Model Evaluasi Kirkpatrick dan Alur Penelitian (sumber: diadaptasi dari Kirkpatrick \& Kirkpatrick (2016)) 
secara objektif yang dalam hal ini adalah kegiatan Design Camp \#1. Data kuantitatif yang didapat kemudian diolah untuk mengetahui persentase, membuat diagram, dan membangun informasi lain dari keempat tahapan evaluasi model Kirkpatrick. Hasil survei juga mampu menunjukan hasil yang terukur dari pengumpulan data responden, data tersebut kemudian dikaji lebih lanjut dalam bentuk deskripsi. Berdasarkan pengertian dari penelitian deskriptif menurut (Suryabrata, 2006) juga bertujuan mengidentifikasi adanya masalah atau kendala yang didukung informasi faktual sehingga sering kali digunakan dalam melakukan komparasi dan evaluasi.

\section{Hasil dan Pembahasan}

Kegiatan Design Camp \#1 diikuti oleh 28 peserta yang terbagi secara acak berdasarkan asal institusi ke dalam 5 kelompok kerja, pembagian kelompok ini dilakukan pada saat acara pembukaan dengan bantuan roda putar (spinning wheel) digital. Sistem pembagian kelompok ini membuat masing-masing kelompok kerja terdiri dari gabungan 2 hingga 3 PTN/PTS yang berisi 4 hingga 6 mahasiswa desain produk. Pembentukan kelompok kerja secara acak ini juga bertujuan untuk memberikan peluang yang sama bagi para peserta dari masing-masing institusi, serta meningkatkan kemampuan untuk bekerjasama dengan sesama peserta. Menurut Sapienza, Goyal \& Ferrara (2018), kerjasama merupakan salah satu sifat dasar yang dimiliki manusia dalam kehidupan sosial dalam rangka meningkatkan kemampuan untuk mencapai tujuan. Pembelajaran secara kolaboratif dalam Design Camp \#1 juga membutuhkan kemampuan berkomunikasi yang baik sehingga sesama peserta dapat saling belajar tentang berbagai hal yang menarik. Berdasarkan data peserta Design Camp \#1 (Gambar 2), sebanyak 82\% atau 23 peserta Design Camp \#1 adalah laki-laki, sedangkan 18\% atau 5 peserta adalah perempuan. Sebagian besar peserta juga berasal dari luar D.I. Yogyakarta, antara lain Jawa Timur, Jawa Barat, Jawa Tengah, DKI Jakarta, Kalimantan Timur, dan dari 5 provinsi lain di Indonesia.
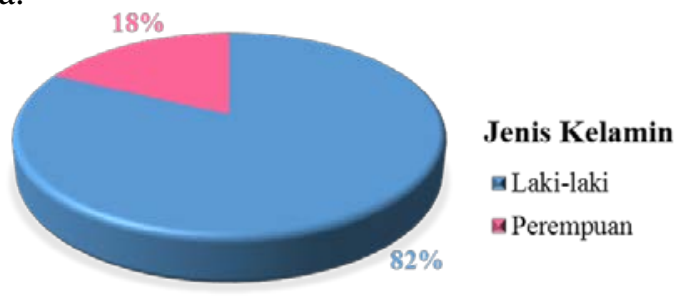

Keberagaman latar belakang peserta Design Camp \#1 dalam kelompok kerja justru menjadi modal yang penting dalam membangun suasana belajar dan mendorong adanya kolaborasi karya antar peserta. Berdasarkan hasil wawancara di awal kegiatan, motivasi sebagian besar peserta mengikuti kegiatan ini adalah untuk menambah teman dan mencari pengalaman. Meskipun tidak menjadi ketentuan dalam kerangka acuan (Term of Rerefence) Design Camp \#1, akan tetapi peserta merupakan mahasiswa semester $6(64,3 \%)$ dan semester $4(35,7 \%)$ yang telah mendapat dasar-dasar pendidikan desain produk di kampus masing-masing. Sebanyak 89,3\% atau 25 peserta juga belum pernah mengikuti kegiatan sejenis (camp), sedangkan 10,7\% atau 3 peserta sudah pernah mengikuti kegiatan seperti ini sebelumnya. Meskipun demikian, seluruh peserta terlihat cukup antusias dalam mengikuti seluruh rangkaian kegiatan Design Camp \#1 mulai hari pertama hingga hari ketiga. Pihak panitia telah mengatur beberapa penekanan kegiatan dalam rangkaian kegiatan Design Camp\#1 agar para peserta dapat fokus pada dalam proses desain secara bertahap. Hari pertama merupakan tahap perkenalan dan pengantar workshop, hari kedua adalah tahap proses kreatif dan kreasi, dan hari ketiga adalah tahap lanjutan proses kreasi dan penyempurnaan. Melalui penelitian evaluatif yang dilakukan dengan model Kirkpatrick, maka rangkaian kegiatan tersebut akan dikaji dalam 4 level yang telah diuraikan sebelumnya, yaitu: Evaluasi Reaksi, Evaluasi Pembelajaran, Evaluasi Perilaku, dan Evaluasi Hasil.

\section{Evaluasi Reaksi}

Para peserta Design Camp\#1 tentunya memiliki banyak kesan dan pesan yang menarik selama mengikuti seluruh rangkaian kegiatan, mulai dari pertemuan pertama antar peserta hingga berakhirnya kegiatan dengan pameran karya. Penyampaian kesan pertama dan testimoni oleh para peserta merupakan cara yang dilakukan untuk mendapatkan data penelitian evaluasi terkait dengan reaksi. Menurut Paull, Whitsed \& Girardi (2016), evaluasi pada level reaksi membutuhkan pandangan dari seluruh peserta

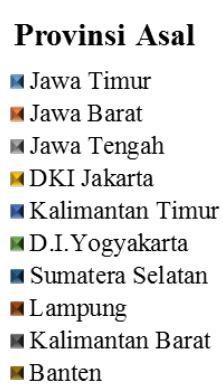

Gambar 2. Profil peserta Design Camp \#1 berdasarkan jenis kelamin dan daerah asal (sumber: dokumentasi peneliti) 
terkait dengan penyelenggaraan rangkaian kegiatan. Evaluasi reaksi juga dapat diketahui lebih akurat paska seluruh peserta mengikuti dan merespon kegiatan yang telah dialami. Selain mendapatkan data melalui wawancara singkat, para peserta juga diminta untuk mengisi kuesioner daring terkait dengan pengalaman peserta yang paling berkesan ketika mengikuti kegiatan Design Camp \#1. Gambar 3 merupakan hasil dari pengisian kuesioner daring oleh seluruh peserta terkait dengan pengalaman yang paling berkesan ketika mengikuti kegiatan. Kalimat yang ditulis oleh para peserta kemudian diolah untuk mendapatkan kata-kata kunci yang muncul dari respon peserta terhadap kegiatan Design Camp \#1. Kata-kata yang terkumpul ini kemudian disaring untuk mencari beberapa kata kunci yang divisualisasikan dalam bentuk awan kata (word cloud) (Gambar 3).

Beberapa kata kunci yang berukuran lebih besar dalam susunan awan kata (word cloud) tersebut merupakan kata yang sering ditulis oleh masingmasing peserta, sedangkan kata yang lebih kecil adalah kata yang jarang ditulis. Lima kata yang paling banyak muncul dalam awan kata adalah baru, saya, bambu, pengalaman, dan banyak. Hal ini menunjukkan bahwa sebagian besar peserta mendapat banyak pengalaman baru yang terkait dengan bambu.

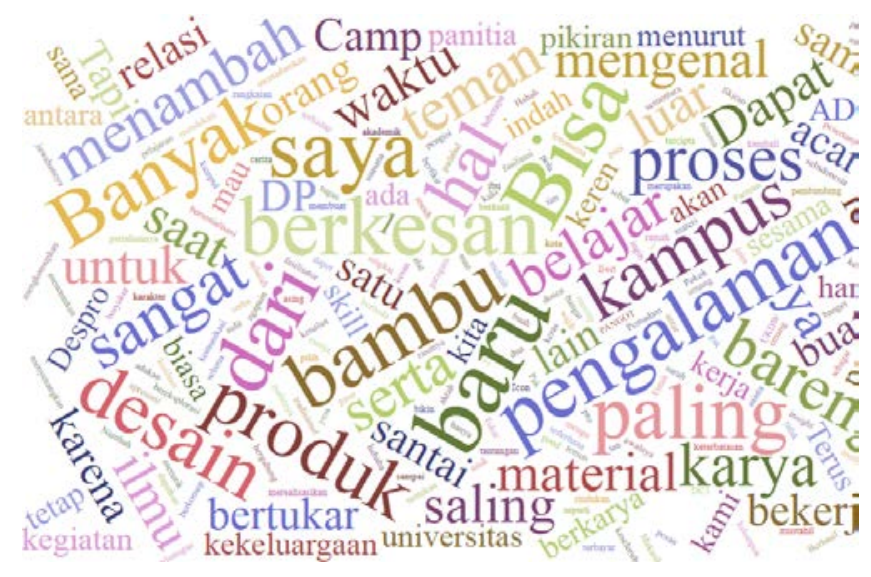

Gambar 3. Awan kata hasil pengolahan testimoni peserta Design Camp \#1

(sumber: dokumentasi peneliti)

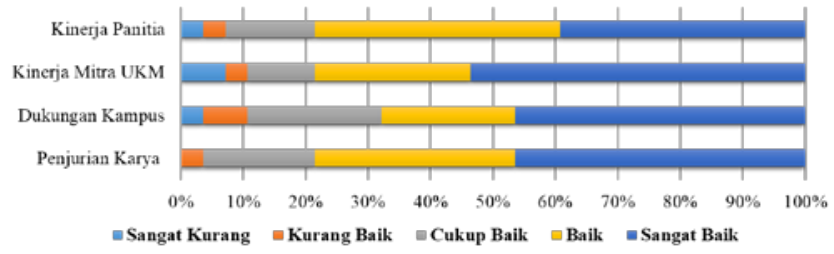

Gambar 4. Hasil Evaluasi Reaksi Peserta Design Camp \#1 Sumber : Dokumentasi Tim Peneliti (2019)
Kata sifat yang banyak muncul seperti banyak, sangat, baru juga menunjukkan bahwa para peserta antusias dalam mengikuti kegiatan Design Camp. Testimoni secara keseluruhan juga menunjukkan bahwa para peserta dapat merasakan hal positif dari rangkaian kegiatan yang diikuti. Penilaian evaluasi reaksi kemudian dilanjutkan dengan kuesioner tingkat kepuasan peserta terhadap beberapa elemen kegiatan, antara lain: kinerja panitia, kinerja mitra UKM, dukungan kampus, dan penjurian karya.

Gambar 4 menunjukkan bahwa keempat elemen pelaksanaan kegiatan Design Camp \#1 mendapatkan penilaian positif oleh para peserta. Kinerja panitia didominasi oleh nilai baik (39\%) dan sangat baik (39\%) selama kegiatan berlangsung karena upaya fasilitasi oleh para pendamping kelompok dilakukan secara optimal demi mendukung kenyamanan dan kreativitas berkarya bagi para peserta. Meskipun demikian, masih terdapat $7 \%$ penilaian yang cenderung kurang baik terkait dengan kurangnya fasilitas akomodasi karena keterbatasan anggaran. Bambu Shinta di Sentra Kerajinan Bambu Sendari sebagai Mitra UKM yang mendampingi para peserta juga mendapat dominasi penilaian sangat baik (54\%) karena mampu mengajarkan sekaligus berkolaborasi dengan para peserta dalam proses pembuatan karya. Penilaian yang kurang baik (3\%) dan sangat kurang baik (7\%) disebabkan karena perajin tidak benarbenar bekerja secara kolaboratif ketika proses perwujudan karya. Dukungan oleh kampus asal para peserta juga mendapatkan penilaian baik (46,5\%) yang menandakan adanya perhatian yang baik dari institusi pendidikan yang mendorong peserta untuk mengikuti kegiatan ini. Selain itu, proses dan hasil penjurian karya juga mendapat apresiasi positif oleh para peserta karena hanya mendapatkan penilaian yang kurang baik sebesar 3,5\%. Terdapat 5 juri yang memberikan penilaian dalam proses berkarya maupun hasil karya secara kolaboratif dalam kegiatan ini. Sebagian besar peserta juga merasa bahwa hasil penjurian oleh para dewan juri sesuai dengan apa yang diharapkan.

\section{Evaluasi Pembelajaran}

Tahap evaluasi pembelajaran merupakan tingkatan evaluasi berikutnya yang dilakukan terhadap para peserta setelah menilai pihak-pihak yang terkait dengan pelaksanaan kegiatan Design Camp \#1. Para peserta dalam evaluasi ini memberikan penilaian terhadap dua aspek pembelajaran yang bersifat reflektif, yakni kesesuaian kegiatan terhadap gambaran peserta di awal kegiatan dan kesesuaian peserta terhadap tema kegiatan. Grafik batang pada 


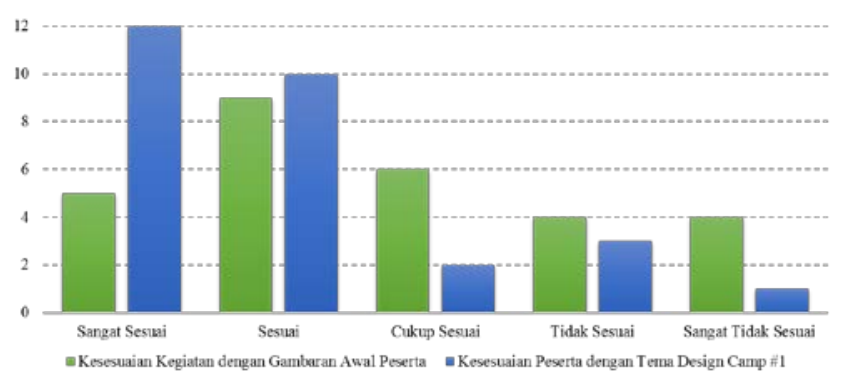

Gambar 5. Evaluasi kesesuaian tema dan kegiatan pembelajaran Design Camp \#1

(sumber: dokumentasi peneliti)

Gambar 5 menunjukkan bahwa sebagian besar peserta merasakan kesesuaian yang tinggi terhadap tema kegiatan Design Camp \#1 yakni Bamboo for Creative Millennials. Tingginya kesesuaian peserta dengan tema (43\%) ini disebabkan karena peserta kegiatan sebelumnya telah menjalani seleksi dari institusi masing-masing. Selain itu, pihak penyelenggara juga memberikan kerangka kerja dan implementasi yang tepat selama kegiatan Design Camp \#1. Meskipun demikian, masih terdapat angka yang cukup signifikan dari ketidaksesuaian dengan gambaran peserta di awal atau sebelum mendaftar terhadap pelaksanaan kegiatan. Beberapa peserta beranggapan bahwa kegiatan belajar ini akan bersifat kaku, pasif dan membosankan, namun sebagian besar peserta justru menunjukan respon positif dengan berpendapat bahwa kegiatan belajar yang diadakan seperti Design Camp \#1 berjalan dengan asik, seru, dan menyenangkan.

Evaluasi pembelajaran juga menunjukkan bahwa peserta juga mengalami peningkatan keterampilan dan pengetahuan, khususnya terkait dengan pengembangan desain produk kerajinan bambu. Keterampilan menurut Sudarto (2016) merupakan kemampuan manusia yang secara teknis dapat digunakan untuk melakukan suatu aksi. Keterampilan manusia sendiri terbagi menjadi 2, yakni keterampilan fisik dan non-fisik/psikis. Kegiatan Design Camp \#1 juga bertujuan untuk meningkatkan keterampilan para peserta, baik dalam hal fisik (olah bambu \& presentasi desain), maupun non fisik (berpikir kreatif \& adaptasi kerja). Di samping mendapat pembelajaran yang mengasah keterampilan, Design Camp \#1 memberikan pengetahuan yang berkaitan dengan desain terhadap para peserta, antara lain pengetahuan bahan bambu, manajemen produksi dalam UKM, dan desain produk kerajinan bambu di Sentra Kerajinan Bambu Sendari. Gambar 6 memperlihatkan hasil kuisioner evaluasi pembelajaran yang terkait dengan pengetahuan dan keterampilan.

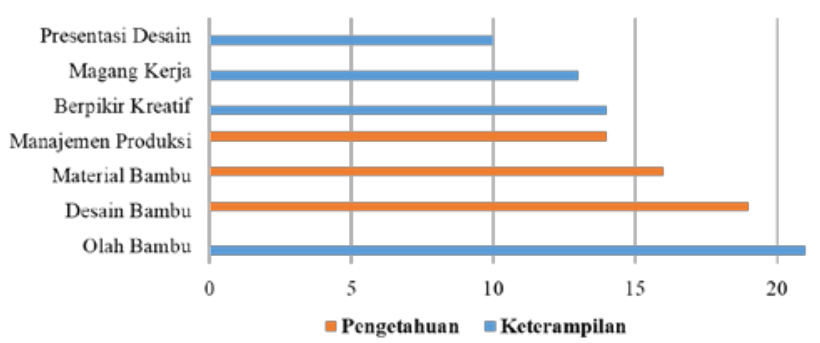

Gambar 6. Evaluasi Pembelajaran kegiatan Design Camp \#1 (sumber dokumentasi peneliti)

Evaluasi pembelajaran merupakan salah satu tahapan yang penting bagi peserta maupun penyelenggara kegiatan karena mampu melihat secara lebih objektif tentang apa yang dapatkan oleh para peserta. Secara keseluruhan grafik pada Gambar 6 menunjukkan bahwa keterampilan olah bambu mendapat nilai tertinggi yang berarti para peserta telah belajar banyak dalam hal ini. Salah satu keterampilan olah bambu yang didapat oleh para peserta adalah penggunaan pisau pangot yang merupakan alat produksi kerajinan bambu khas Sentra Kerajinan Bambu Sendari. Menurut Rönkkö \& Aerila (2015), aktivitas membuat kerajinan yang menuntut keterampilan tangan (hands-on) ternyata mampu meningkatkan kreativitas dan kemampuan menyelesaikan masalah. Selain itu, aktivitas berkarya juga membuat para peserta Design Camp \#1 mampu menguji gagasan atau ide desain yang telah dipikirkan sebelumnya ke dalam sebuah purwarupa.

\section{Evaluasi Perilaku}

Evaluasi perilaku para peserta Design Camp \#1 dalam merupakan tahapan ketiga yang menarik untuk dikaji melalui model Kirkpatrick. Peserta yang terdiri dari beragam latar belakang memiliki perilaku yang berbeda-beda sebagai individu, namun mampu beradaptasi sebagai sebuah kelompok. Peserta mampu menunjukan penerapan hasil belajar, khususnya keterampilan berkarya yang didapat dari para perajin bambu sebagai pendamping atau mentor. Menurut Rönkkö \& Lepistö (2016), pembelajaran dalam konteks kerajinan (craft learning) selain mengasah pengalaman berkarya, juga meningkatkan keterampilan personal, kepercayaan diri, dan kemampuan untuk masuk dalam lingkungan sosial. Keempat hal ini juga mampu mendorong kemampuan peserta dalam mengambil keputusan-keputusan yang hendak diterapkan dalam desain produk. Pengambilan keputusan (decision making) secara cepat dan tepat dalam proses desain produk juga merupakan bagian 
yang dikembangkan oleh para peserta sebagai salah satu kompetensi yang mendukung keberhasilan. Dalam konteks pembelajaran kolaboratif, keberhasilan desain merupakan pencapaian bersama yang lebih ditentukan oleh faktor internal dalam tim desain. Oleh karena itu, hasil kuesioner paska pelatihan yang diperlihatkan Gambar 7 menunjukkan bahwa peserta cenderung memilih teman sekelompok (38\%) sebagai aspek yang paling kuat dalam menentukan keberhasilan dalam proses desain.

Teman sekelompok menjadi aspek keberhasilan yang mendominasi pilihan peserta dalam proses mendesain. Di samping itu, persentase perajin bambu sebagai mentor (29\%) berada tepat di bawah teman sekelompok. Perajin bambu dalam kegiatan Design Camp \#1 juga memiliki peran yang hampir sama untuk melalukan kolaborasi dengan para peserta. Perilaku berkarya secara kolaboratif inilah yang memegang peran penting dalam menentukan keberhasilan kelompok dibanding berkompetisi. Melalui survei yang dilakukan paska kegiatan, 15 dari 28 peserta memilih untuk berkolaborasi penuh dalam proses mendesain selama kegiatan Design Camp \#1 meskipun terdapat peluang kompetitif di antara peserta. Gambar 7 memperlihatkan hasil evaluasi terhadap kecenderungan perilaku kolaboratif oleh para peserta.

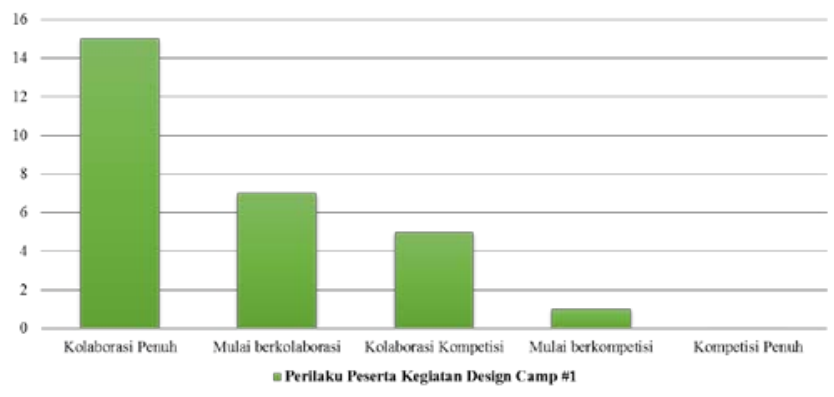

Gambar 7. Kecenderungan kolaborasi dan kompetisi dalam proses berkarya

(sumber: dokumentasi peneliti)

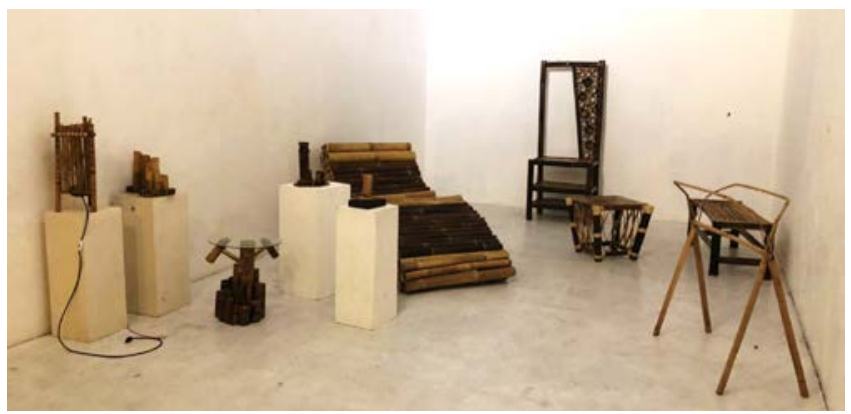

Gambar 8. Hasil Karya Peserta Design Camp \#1 : Bamboo for Creative Millenials

(sumber: dokumentasi peneliti)

\section{Evaluasi Hasil}

Hasil karya dari kegiatan Design Camp \#1 merupakan salah satu indikator keberhasilan pelatihan yang ditempuh oleh para peserta selama 3 hari. Karya desain kerajinan bambu yang dihasilkan juga menunjukan kreativitas dan pengaruh dari pembekalan yang diberikan oleh berbagai narasumber di awal kegiatan. Peserta yang terbagi ke dalam 5 kelompok telah menghasilkan karya desain kerajinan bambu dengan gagasan dasar yang berbeda satu dengan yang lain. Proses pembelajaran yang didapat melalui kegiatan Design Camp \#1 juga mampu mendukung motivasi peserta untuk terus meningkatkan kapasitas sebagai calon desain produk. Berdasarkan hasil kuisioner, sebanyak 67,9\% peserta Design Camp \#1 berencana untuk terus mengembangkan desain produk yang telah dihasilkan, sedangkan 32,1\% peserta masih ragu-ragu untuk mengembangkan. Desain kerajinan bambu yang dihasilkan juga mendapat apresiasi dari beberapa pelaku usaha di Sentra Kerajinan Bambu Sendari karena gagasan desain tersebut belum pernah muncul sebelumnya (Gambar 8).

Hasil yang didapat oleh peserta melalui kegiatan Design Camp \#1 menurut para peserta juga mampu mendukung perjalanan karir sebagai desain produk. Sebanyak 60,7\% peserta sangat setuju bahwa kegiatan seperti ini mampu mendukung karir sebagai desainer produk karena lebih bersifat praktek dan terjun langsung ke UKM sebagai salah satu bentuk magang kerja meskipun dalam waktu yang sangat singkat. Menurut survei peserta Design Camp \#1, kegiatan semacam ini sebaiknya dilaksanakan selama 5 hingga 7 hari sehingga memiliki cukup waktu untuk berekplorasi. Evaluasi hasil juga menunjukan bahwa 82,1\% peserta ingin kembali mengikuti acara seperti ini apabila ada kesempatan. Hasil ini menunjukkan bahwa pelaksanaan kegiatan Design Camp \#1 mampu menarik minat belajar dan berkarya bagi para peserta.

\section{Kesimpulan}

Design Camp \#1 sebagai kegiatan kemahasiswaan di tingkat nasional menjadi ajang belajar dan berkarya bagi mahasiswa Program Studi Desain Produk antar perguruan tinggi di Indonesia. Selain mengasah keterampilan dan menambah pengetahuan, kegiatan seperti ini juga menambah relasi serta meningkatkan kemampuan berkolaborasi kepada peserta. Kemampuan untuk bekerjasama dan bekerja dalam tekanan waktu merupakan salah satu yang tidak secara nyata diasah dalam kegiatan ini. Hal ini dapat terlihat dari kemampuan para peserta dalam 
beradaptasi dengan cepat ketika mengambil keputusan desain hingga mewujudkan karya bersama dengan perajin sebagai pendamping. Proses berkarya selama 2 hari kerja merupakan tantangan yang mampu diselesaikan oleh para peserta dalam merancang desain produk beserta purwarupanya. Berkarya dalam waktu yang terbatas ternyata dapat diselesaikan melalui dukungan teman kelompok dan upaya kolaborasi dengan perajin. Bagi pelaku usaha di Sentra Kerajinan Bambu Sendari, kegiatan Design Camp \#1 merupakan salah satu bentuk edukasi peran profesi desainer produk di tengah UKM. Meskipun kegiatan dengan bentuk seperti ini telah mendapatkan penilaian positif dari para peserta namun tetap harus terus dikembangkan agar semakin bermanfaat bagi kemajuan pendidikan desain produk di Indonesia. Ucapan terima kasih disampaikan kepada segenap panitia dan peserta Design Camp \#1, Universitas Kristen Duta Wacana dan seluruh Perguruan Tinggi Penyelenggara Program Studi Desain Produk yang tergabung dalam Anggota Afiliasi ADPII (Aliansi Desainer Produk Industri Indonesia) yang telah mendukung terlaksananya penelitian ini.

\section{Daftar pustaka}

Badu, S. Q. (2012). Implementasi Evaluasi Model Kirkpatrick Pada Perkuliahan Masalah Nilai Awal Dan Syarat Batas. Jurnal Penelitian dan Evaluasi Pendidikan, Edisi Dies Natalis ke-48 UNY. 16. 102-129

Kirkpatrick, D. \& Kirkpatrick, J. (2016). Evaluating Training Programs: The Four Levels, Berrett-Koehler Publisher
Komnenić, B., Borovnjak, A., Filek, S, \& Velinovski, A. (2015). Practicing Design: Rethinking Design Education. Zagreb: Public Room Skopje

Paull, M., Whitsed, C. \& Girardi, A. (2016). Applying the Kirkpatrick model: Evaluating an Interaction for Learning Framework curriculum intervention. Issues in Educational Research, 26 (3). 490-507

Rowe, A.,\& Wong, K. (2011). Design pedagogy competencies: cross-cultural collaboration for a changing future. DesignEd Asia Conference 2011, Nov 29-30, Hong Kong. Retrieved Juli 28, 2019, from https://repository.vtc.edu.hk/ive-de-sp/26

Rönkkö, M.-L. \& Aerila, J.-A. (2015). Children designing a soft toy: An LCE model as an application of the experiential learning during the holistic craft process. Techne Series: Research in Sloyd Education and Craft Science A, 22 (1). 4458

Rönkkö, M.-L., \& Lepistö, J. (2016). The craft process developing student decision making. Techne Series: Research in Sloyd Education and Craft Science A, 23 (1). 48-61

Sapienza, A., Goyal, P., \& Ferrara, E. (2018). Deep Neural Networks for Optimal Team Composition. Proceedings of ACM. Retrieved Juli, 28, 2019, from https://arxiv.org/pdf/1805.03285.pdf

Sudarto. (2016). Keterampilan dan Nilai sebagai Materi Pendidikan dalam Perspektif Islam. Jurnal Al-Lubab, 1 (1). 105-120

Sugiyono. (2012). Metode Penelitian Kuantitatif Kualitatif dan $R \& D$. Bandung: Alfabeta.

Suryabrata, S. (2006). Metodologi Penelitian. Jakarta: Raja Grafindo Persada

Syahrum \& Salim. (2012). Metodologi Penelitian Kuantitatif. Bandung: Ciptapustaka Media

Westbomke, J., Nyström, Sutter, R., \& Bogaert, L. (2011). Intercultural Design Camp - Facing New Challenges In An International Cooperation Of European Universities. ICERI2011 Proceedings. 1189-1198. Retrieved Juli, 28, 2019, from https://library.iated.org/view/WESTBOMKE2011INT 